\title{
The Nineteenth Century Apostolic Christian Church: The Emergence, Establishment, and Fragmentation of a Neo- Anabaptist Sect
}

Joseph F. Pfeiffer

Doctoral student

School of Intercultural Studies

Fuller Theological Seminary

\begin{abstract}
This article traces the emergence, proliferation, and identity formation of a 19th century NeoAnabaptist sect known variously as Neutäufer (New Anabaptists), Nazarenes, and Apostolic Christian Church. The Neutäufer emerged during an era that was a turning point in world religious history, marked by a renewed sense of missionary vigor and the proliferation of major voluntary (as opposed to state-driven) religious movements. These movements radically transformed Western, and even global, Christianity. The article gives detailed attention to the role of Samuel Heinrich Fröhlich in synthesizing evangelical renewalist impulses with traditional Anabaptist convictions. It also follows the tensions that emerged, where agreed upon centrally held traditional Anabaptist values-e.g. non-conformity, plainness, and separation from the world - came to be understood differently as the movement diversified beyond its original context. This article not only contributes to the historical study of the Neutäufer but also contributes to understanding the sociological dynamics of the emergence, establishment, and fragmentation of religious sectarian movements more generally.
\end{abstract}

\section{Keywords}

Apostolic Christian Church; Neo-Anabaptist; Anabaptist; Samuel Fröhlich; Sectarian identity formation; Nazarene

\section{Acknowledgements}

Many thanks to the numerous members and former members of the Apostolic Christian Churches when I conducted fieldwork, and also for helping me find important documents related to Apostolic Christian Church history. 


\section{Introduction}

The Apostolic Christian Church (also known as Neutäufer, or Nazarenes in Eastern Europe) provides a fascinating case study of the emergence, sectarian formation, and development of a Neo-Anabaptist movement. What is furthermore unique about the Apostolic Christian movement, in contrast to similar Anabaptist movements, is its diversity in terms of language, geography, and socioeconomic context. This provides a unique opportunity to compare and contrast how a common sectarian neo-Anabaptist religious identity develops in these different contexts.

This article is divided into three sections, covering critical formative stages in the development of the Apostolic Christian Church tradition. The first section covers the emergence of the Neutäufer movement in Switzerland and Western Europe and factors that contributed to its development from an evangelical-Pietist renewal movement to an exclusivist Neo-Anabaptist sect, with special attention to the movement's founder, Samuel Heinrich Fröhlich. The second section covers the development of the American Apostolic Christian Church from the 1840s to the turn of the century. Of particular note is the adoption of the Fröhlichite movement among the first generation of immigrant Amish communities on the American frontier and of the gradual and subtle development of a unique American Apostolic Christian sectarian identity amidst wider social and cultural developments as the frontier developed and transitioned into the American Midwest region. The third section looks at the new challenges that came about as large numbers of Nazarenes (the branch of the Fröhlichite movement that developed separately in Hungary) immigrated in large numbers to North America, settling among their fellow co-religionists. Ultimately, this pluralism of differing cultural understandings of worldliness and plainness became too difficult for many leaders of the American Apostolic Christian Church tradition to bear, resulting in a major division around the turn of the 20th century; the two major successor associations were the Apostolic Christian Church of America and the Apostolic Christian Church (Nazarean).

\section{Samuel Heinrich Fröhlich and the Swiss Neutäufer: From Evangelical Renewal to Neo-Anabaptist Sectarian Movement}

\section{Early Life, Education, and Pietist Influences}

The Neutäufer movement emerged in Switzerland in the 1830s, under the charismatic leadership of Samuel Heinrich Fröhlich (1803-1857), originally from Brugg in Canton Aargau. The son of devoutly religious parents, who were descendants of French Calvinist Huguenots that had fled to Switzerland in the late seventeenth century, Fröhlich's parents had him groomed for ordained ministry in the State Reformed Church of Switzerland from an early age, sending him to some of the most prestigious educational institutions of his day - the Collegium Humanitatis and Gymnasium Carolinum in Zürich—where he was thoroughly trained in classical languages and philology. In 1823, at age twenty, Fröhlich enrolled in the University of Basel to begin 
formal studies in theology, in preparation for ordained ministry. There, he studied under the famous nineteenth century rationalist theologian and Bible scholar, Wilhelm Martin Lebrecht DeWette. ${ }^{1}$ Fröhlich, heavily influenced by the rationalist theology of both his Zürich and Basel mentors, renounced to his parents beliefs in such supposedly superstitions as "Hell, the Devil, etc.” Furthermore, he described his studies during this time as mechanical, rote, and passionless, as one "preparing more for a professional trade than a calling" (Fröhlich 1978b, 4). Disturbed, Fröhlich's parents had him referred to a Pietist-inclined student chaplain (Studentenseelsorger) at Basel, who also directed Fröhlich to a Moravian Pietist student conventicle. Fröhlich was at first put off by their exhortations to "self-knowledge" and soul-searching, which leads to conviction of sin and repentance toward a godly life. However, after a powerful conversion experience, where Fröhlich records that a gentle, yet direct and convicting voice said to him, "It cannot remain thus with thee. Thou must change,” Fröhlich’s disposition changed dramatically. Renouncing rationalism and the liberal theology of his university education, Fröhlich endeavored to preach a gospel of repentance of sins, experience of the New Birth, faith in Christ's atoning sacrifice on the cross, and amendment of life toward godliness, much in line with the German and French Awakening (Erweckungsbewegung and Reveil) movements of his time (Lehmann 2000, 1-26).

After some difficulty with the State Church authorities due to his outspoken evangelical beliefs, Fröhlich eventually was given oversight of a parish in Leutwil, Canton Aargau, in December 1828, an area Fröhlich mentions was infamous for its depravity. Preaching his evangelical message there "as the voice of one in the wilderness," an evangelical awakening took place in the large congregation $(1,800)$. People came from miles away to hear his preaching (Fröhlich 1978b, 11). This attracted the attention and censure of officials in the State Church Consistory. In September 1830, Fröhlich was dismissed from the State Church ministry and prohibited from all preaching and sacramental activities for refusing to adopt the newly established rationalist confession of faith, which was to replace the traditional Heidelberg Catechism.

\section{From Evangelical Renewalist to Dissenting Anabaptist}

After his dismissal from ministry in the State Church, Fröhlich only became increasingly radicalized in his evangelical convictions. At the end of 1831, Fröhlich wrote that the option of continuing in the ministry of the State Church was not out of the question but that he saw little prospect of being able to carry on the work that he desired to accomplish. He continued also for a short pastorate in Wilhelmsdorf, in Württemberg, Germany, in a congregation that had similarly separated from the State Church because of imposed liturgical reforms. Nevertheless, this congregation was only willing to go so far with Fröhlich's more radicalized convictions, including believers baptism (Ruegger 1949, 41).

Fröhlich had begun to doubt the doctrine of infant baptism even as he ministered in the State Church and taught the traditional catechism (Fröhlich 1978b, 12). By February 1832, his 
convictions were sealed as he submitted himself to adult believers' baptism at the hands of Ami Bost in Geneva, a prominent French evangelical revivalist who himself had developed a conviction about the imperative of an adult believers' baptism. Fröhlich could then write to the Baptist Continental Society with full conviction in his doctrinal statement that the qualifications for baptism were sincere repentance, faith, and a renewed heart-by which definition, infant baptism did not qualify as true baptism (Fröhlich 1978b, 19-20).

In the early 1830s, Fröhlich began looking for a new home among many of the smaller Free Church and missionary groups that were emerging during this period in Western Europe. He had even looked into foreign mission work through the Basel Mission - a major regional center of the nineteenth century foreign missions movement-but was discouraged from this due to a lack of language preparation and his poor health (Fröhlich 1978b, 14). He thus sought support for a more domestic missionary endeavor. A number of organizations were rising up to evangelize continental Europe during this time. One of these was the Baptist Continental Society. The Baptist Continental Society was formed to serve as a resource and an outlet for a specifically Baptist mission on the Continent; their strategy was to connect with local leaders and preachers of emerging believers' baptism-oriented congregations, to support and guide their work (Fath 2003).

\section{Itinerant Ministry, Formation of a Neo-Anabaptist Movement}

Throughout the duration of its short life (1831-1836), Samuel Fröhlich was affiliated with the Baptist Continental Society, even as he continued to work in an itinerant ministry among various emerging independent and Free Church groups, preaching his message of believers’ baptism and conversion. The Society financially supported his work, as well as for Ami Bost in Geneva. During this time Fröhlich engaged in the five "missionary journeys" that would be foundational in shaping his thought, ministry, and the movement that grew up around him.

In the first missionary journey, Fröhlich traveled from Brugg to the vicinity of his former parish in Leutwil, where he stayed from April 13 to May 6, 1831. There, Fröhlich reconnected with many of his former parishioners and held daily meetings with them in the evenings, where he preached his message of repentance, renewal, and baptism of faith. Ruegger reports that word quickly spread of Fröhlich's return. His evening meetings included some 200-300 people. Within eight days, 38 of these received believers' baptism-after questioning and examination, if they were willing to "count the cost" of following Jesus. With these, he began to celebrate the Lord's Supper, and a new congregation was born (Ruegger 1949, 44). This journey would also mark the beginning of Fröhlich's encounter with official persecution. On May 6, after two weeks of ministry, the meeting was broken up by the police as an unauthorized conventicle. Fröhlich was taken before a magistrate on these charges. After this, Fröhlich returned to Brugg, now a marked man. 
Fröhlich’s second missionary journey took him to the Bernese highlands, July-August, 1832. He originally set out to meet Ami Bost, who was in the area, but Bost had already departed. Nevertheless, Fröhlich continued to travel around the region, holding meetings with those open to his message. This included a meeting with a Pietist-minded conventicle led by a friendly government official and with a "believing" pastor in Lauterbrunnen, who accompanied Fröhlich for part of his journey in the area. Though no congregations were immediately founded, we see here the appeal that Fröhlich's message had among many in the Reformed State Church who sensed a need for renewal and were happy to have someone such as Fröhlich preach. Nevertheless, Ruegger (1949) records that it was here that Fröhlich learned "not to take too much for granted with the people" but to "lay the right foundation first" in order to build with more certainty (p. 46). Here we see Fröhlich’s increasing tendency to caution in terms of judging the spiritual condition of others.

Fröhlich’s third missionary journey of August 1832, was in the Emmen Valley (Emmental) region, where he visited extensively with the remnants of the Emmental Mennonite communities in the vicinity of Langnau. The Emmental region had long been a center for Anabaptist-Mennonites in Switzerland, dating back to the early sixteenth century and the emergence of the Anabaptist movement in Switzerland. Fröhlich had made contact with Christian Gerber and Christian Baumgartner, leaders of the Emmental Mennonite congregation, who were seeking renewal for their congregation and its evangelical Anabaptist principles. Gerber especially had considered that the discipline of the younger preachers had become too lax and saw Fröhlich’s teachings as a stimulus for renewal (Gratz 1953, 114-15). Ruegger $(1949,48)$ reports that he preached to a combined audience of about 400 to 500 persons.

Fröhlich was attracted to this community because of their traditional doctrines of believers' baptism. While these leaders of the Emmental Mennonite community had welcomed much of Fröhlich's preaching on repentance of sin and baptism of faith, they challenged him that his principles of faith did not address the issue of military service. Nonresistance would be one Anabaptist doctrine that eventually came to be a major component of Fröhlich's developing faith and movement. From the Pietist and Neo-Pietist impulses mediated through the Reveil movement, Fröhlich came to emphasize an experiential, heartfelt conversion that only came about through the inner struggle (Busskampf) of godly sorrow over sin and true repentance to God. The influence of Anabaptist-Mennonite belief had convinced Fröhlich that baptism and communion within the brotherhood of believers must go hand in hand. There is no place for a disembodied church. Baptism and conversion must of necessity involve a covenanted relationship with a distinct and visible corporate body of believers on earth. This had long been a central Anabaptist tenet since the sixteenth century. From the Anabaptists, Fröhlich gained an integral ecclesiology, of a people set apart in the world as a community of suffering crossbearing disciples, following the Savior along the narrow way to the heavenly homeland. Fröhlich would also come to adopt the Swiss Anabaptist system of church government, based upon the 
leadership of Elders (Aeltester) and preaching brothers or Lehrbrüder (see Krahn and Friesen 1989). These seeds would grow and blossom together.

In the course of his life, Fröhlich and his movement would come to be profoundly shaped by Anabaptist thought and doctrine in a fundamental way, distinguishing it from the other European movements, including Baptist movements, springing from the nineteenth century evangelical Awakening (Erweckungsbewegung). The evangelical and Pietist movements tended to emphasize the inner spiritual life and conversion and moral formation of the converted individual. Anabaptism provided a corporate ecclesiological identity and discipline.

Fröhlich's fourth missionary journey took him to East Switzerland during OctoberNovember 1832. Congregations would come to be established around Zürich, St. Gallen, and Hauptwil in Canton Thurgau, many stemming from Pietist home fellowships and conventicles that he had visited. During his itinerant travels, Fröhlich found numerous Pietist home fellowships or conventicles that were open to his message and would become the basis for establishing new free congregations. One example was a radical Pietist group called the "Inspireds" (Inspirirten), who had met in secretive meetings in private homes and were drawn to join his movement in 1835 (Hadorn 1901, 238). Many such groups had formed because of their dissatisfaction with the spiritual condition of the State Church and their desire for a faith that emphasized personal renewal and more faithful living. This region would come to be in time the geographical center of Fröhlichite movement in Switzerland (cf. Ott 1996, 45).

Next, Fröhlich spent from the end of January until June 1833 in London, at the invitation of the Continental Society, for the purpose of getting to know the leaders of the Society and to better learn English. However, during his stay, Fröhlich became aware that the Continental Society could no longer support him or Bost due to lack of finances. While in London, Fröhlich is reported to have spent time with the "Strict Baptists." The "Strict Baptists" considered themselves the true heirs of the Particular Baptist tradition, which adhered quite closely to Calvinism, and the practices of closed communion only among baptized members (McBeth 1987, 521-22; cf. Garrett 2009, 198-200). Ott (1996, 43-44) notes that this experience likely solidified Fröhlich's own developing strict views on these matters; Fröhlich's return from London would represent a new period in the nature of Fröhlich's life and work, marking a shift from an itinerant evangelist to an organizer and builder of congregations. Also by this point, the foundations of Fröhlich's theological formation had been laid. He now had a vision of a set apart Church community based upon the New Testament model of the early Apostolic Christian churches.

\section{Fröhlich’s Doctrine of Baptism and Salvation}

The year 1836 marked a definitive year in the history of Fröhlich’s movement. This was no doubt due in part to Fröhlich's emerging teaching of baptismal regeneration and perfectionism. A letter from that year from Brugg (Fröhlich, n.d., 486-91) gives his strong 
interpretation of Hebrews chapter 6, that there is no possibility of a second repentance for Christians who have experienced the true baptism of the Spirit. Moreover, by August of that year, it became clear that Fröhlich's last efforts to bring about a union with Baptists in England had failed (Ruegger 1949, 55-56). As Fröhlich came to define more precisely his radical views on baptism, tensions mounted, leading to the separation of most of the congregations of Western, French-speaking Switzerland, which Fröhlich had been affiliated with since the early days of his itinerant evangelistic ministry. In a letter to an associate in Bern, November 1836, Fröhlich noted the differing views of baptism. Whereas the congregations of French West Switzerland saw baptism as a forgiveness of sins, Fröhlich considered this view deficient—Fröhlich and his followers would sometimes refer to it as the “Baptism of John.” In Fröhlich’s view, the baptism of Christ literally effects the death of the sinful nature and the new life of Christ, the new Adam (Fröhlich, n.d., 495-96). Most of these French-Swiss congregations later joined the Darbyite movement (Ott 1996, 51-52; Ruegger 1949, 145-47). Fröhlich and his movement were now isolated, and a strong spirit of separatism, even from other Baptist and Anabaptist movements, came to define Fröhlich’s emerging sect.

From this time to his untimely death in 1857, Fröhlich continued to set the doctrinal tone for the Neutäufer movement in Europe, through his teaching and writings. Two theological treatises published in 1838 outline the core of his theology and worldview. The first, published in St. Gallen, was titled: Das Geheimnis der Gottseligkeit und das Geheimnis der Gottlosigkeitnach ihrem Wesen und in ihrem Gegensatze zu einander beleuchtet ausdem Worte Gottes ("The Mystery of Godliness and the Mystery of Ungodliness-Their Natures and their Oppositions to each other illuminated by the Word of God”). In the first treatise, Fröhlich argues that there are essentially two mutually opposed kingdoms at work in the world: God's Kingdom and Satan's Kingdom. To be a part of one is to preclude participation in the other. Fröhlich presents a cosmic picture of God's salvific work that goes beyond the individual to the cosmic war between these two kingdoms. Salvation, Fröhlich argues, is not merely the justification of the individual sinner from Adam's fall; it is the sanctification of true believers in lives of holiness and discipleship in a set apart community that is called out of Babylon. For Fröhlich, this metaphorical Babylon, the Beast of Revelation 14, from which the followers of Christ are called out and sanctified, is none other than the State Church system and those captive to its seductive power.

The second was published later in 1838 as Die Erretung des Menschen durch das Bad der Wiedergeburt und die Erneuerung des heiligen Geistes-Eine schriftgemaesse Eroerterung ueber die Taufe in Christum ("The Salvation of Man through the Washing of New Birth and the Renewal of the Holy Spirit-A Scriptural Discussion Concerning Baptism in Christ”). In these treatises, we find the best articulation of Fröhlich's distinctive theology of human nature, sin and salvation, regeneration, the nature of baptism, and the true Christian Church. In Fröhlich’s understanding, repentance alone was not sufficient. What Man needed was to be made into a new creation altogether, whereby the old sinful nature of Adam was washed away and replaced by the new spiritual nature of Christ. This Fröhlich understood to be the baptism "with the Holy Spirit 
and with fire” that John the Baptist prophesied as Christ's baptism (Fröhlich 1978a, 85-89). So radical was the spiritual transformation and conversion to be that the marks of original sin were washed away and the believer would no longer sin. In this, Fröhlich would resemble considerably Anglo-American holiness groups that preached a sinless perfectionism, known as “Christian Perfectionism” or “entire sanctification” (cf. Dieter 1996). Unlike these groups, however, Fröhlich linked this experience of entire consecration and regeneration in the Holy Spirit to the baptismal experience. Baptism was thus more than simply a sacred rite but an allencompassing worldview paradigm. In Christ, truly a new epoch had come, with the outpouring of the Holy Spirit and the power of humanity to have a new nature in Christ. But with this new identity also came the responsibility to take care and endure, lest one find himself as the disobedient “faithless servant," forfeiting the inheritance in God's Kingdom.

\section{A Community of Exiles on the Earth}

A combination of bitter disappointments and socio-political circumstances had a definite effect on Fröhlich's developing worldview and theology. His was certainly a theology on the move. Due to his growing reputation as a sectarian, he was increasingly a fugitive moving from town to town, conducting meetings for worship and preaching, which were often disrupted by the police. The consequences for meeting could be dire, often including stiff fines, imprisonment, and even violence. Nonetheless, the movement persisted, and the theme of suffering for the sake of Christ and enduring to win the victory of faithful obedience became central themes in the many Bible studies that Fröhlich led and letters he wrote during the 1840s, both in Switzerland and, finally, in exile in Strasbourg, where he remained until his death in 1857.

The Zion's Harp, a collection of hymns and songs, became a central focus and symbol of Apostolic Christian identity and devotion. A number of the songs present the ideal picture of a church of harmony, peace, and brotherhood set apart from a world of unbelief, evil, and discord. Most of the hymns come from Pietist and Lutheran sources, with a strongly devotional theme. Additionally, G.M. Mangold—one of the early Swiss Neutäufer—contributed 26 original songs, many of them on themes about counting the cost of being Christ's disciple and willingness to endure suffering for his sake (Moser 1973, 55). A number of these were written during Mangold's time in prison.

Every instance of opposition-from the failure of the state to recognize Fröhlich's marriage in an unrecognized illegal sect, to persecution, to criticism by other evangelical groups such as Johann Gerhard Oncken's own German Baptist movement-became an instance to reflect on the trials from Satan that the true Christian must endure and overcome for the sake of faithful obedience to Christ. A martyr identity became central to Fröhlich and his movement, and would be reinforced by persecution of various forms of his followers in both Western and Eastern Europe for more than a century. 
Fröhlich's writings evidence a thorough familiarity with early Christian history, and his theological reflection on the nature and structure of the Church resembles strongly the purist impulses of ante-Nicene Christianity. Garfield Alder (1980, 38, 192-93) especially notes an affinity in Fröhlich's theology of baptism and holiness with that of Tertullian, representative of the strict and separatist North African Church of the third century. Indeed, Fröhlich's Taufgesinnte Geimende increasingly took on a "martyr" identity and theology in the face of Fröhlich's exile from Switzerland and continuous persecution and marginalization by the Swiss state authorities. They came to identify with the Early Church, suffering for Christ's sake, rejected by the world.

This was perhaps most fully elucidated in a substantive book written by Fröhlich's associate, G.M. Mangold, Blicke in die Vergangenheit, Gegenwart und Zukunft. First published in 1862 (later translated as Meditations upon the Past, Present, and Future), this book gives a detailed interpretation of the biblical book of Revelation, interpreting the bride of Christ as the faithful, remnant church, persecuted by the whore of Babylon, which is the official State Church. In his reading of history, the fall of the majority church began with the introduction of superstition, the "perverse" doctrine of infant baptism, and alliance of the Church with the Roman Emperor Constantine (Mangold 1950, 63-67). It reached its apotheosis in Augustine’s doctrine of ex opere operato, remarking, "upon such a foundation rests the entire structure of the worldly church, the outward form, and nominal Christendom” (p. 95). Drawing directly from Radical Pietist Gottfried Arnold's alternative reading to conventional accounts of Church history (in his Unpartheyische Kirchen- und Ketzer-Historien), those that the mainstream Church has historically deemed "heretics" — such as the Donatists, Novationists, Waldensians, and Anabaptists - were in reality the bearers of the remnant of pure apostolic Christianity in exile (Stoeffler 1973, 175-76). In the mid-nineteenth century, it was Fröhlich’s Apostolic Christian Taufegsinnte that bore this witness in a hostile world of false Christianity.

Purity in doctrine and practice was paramount to preserving the faithful apostolic witness, no matter the cost. Issues going on in Fröhlich's community mirror developments among similar restorationist groups, such as the Plymouth Brethren. For instance, the Plymouth Brethren leader Darby took a similar stance as Fröhlich toward the church and its essential unity on earth during the division within the Plymouth Brethren into the "Open Brethren” and the "Exclusive Brethren.” When Darby and his meeting expelled one member, he insisted that all other meetings in communion with his also consider that person out of communion; since there was only one church of Christ, it would be inconceivable for someone to be in communion with one congregation but not with another (Durnbaugh 1968, 170). It was for the similar reason that, because certain of his former fellow church members had been expelled and subsequently joined other Baptist type churches, Fröhlich later in his life refused to involve his movement in transdenominational conferences or ecumenical endeavors. ${ }^{2}$

Sociologist Werner Stark $(1970,31)$ has written about the vital place that religious leaders play in the founding and center of a religious movement.. The charismatic leader as 
founder leads a "secession" to form the new "cleansed" clan, out of the old "soiled" one. In a time of upheaval and disaffection with the religious status quo, Fröhlich truly became the center of a movement that drew from a number of sources. People of every tribe and tongue seemed to gather out of the nations into a new, sanctified, people of God. His movement provided a synthesis that was relevant to the times in need of renewal.

Fröhlich became the leader of an indigenous, organic sectarian movement in Central Europe. Indeed, Fröhlich served as the unifying figure of a geographically widespread and ethnically varied community, weaving together various strands of Continental Pietism and Radical Pietism, Reveil and German Awakening impulses, and influences from English Evangelical and Baptist movements, contributing to a phenomenon that resembles many of the principles of other contemporary Restorationist movements. His movement also brought together people from a number of ethnicities, including Swiss-German, German, French, Swiss-French, Swiss Mennonite, Hungarian, and, eventually, Serbs, Romanians, and others.

Though never traveling to America or to Hungary, and only seldom in the last thirteen years of his life back to his native Switzerland, the heartland of the movement, Fröhlich continued to unify and guide this movement through lively and active written correspondence. Even so, the seeds planted would take on the characteristics of the soils in which they were planted, as the movements manifested in differing social and cultural contexts.

\section{From Sectarian Movement to Institutional Sect: The nineteenth Century Apostolic Christian Church in America}

\section{Early Nineteenth Century Anabaptist Migrations to North America}

Small numbers of Neutäufer followed the early German migrations to North America in the late 1830s and early 1840s. But these were too few and scattered to organize congregations like those in their homeland. They did, however, spread word of the dynamic movement among fellow German-speaking immigrant settlers. This especially sparked large scale interest in the Neutäufer movement by one particular German speaking ethnic group that had been settling in large numbers in the frontier areas of the old Northwest since the early 1830s- the Amish.

The years 1820 to 1860 saw one of the largest mass migrations of Amish to North America (Nolt 2003). Most of these were from Alsace and Lorraine in France, where the Amish had their strongest center in Europe. Leaving due to the increasing pressures of military conscription following the French Revolutionary and Napoleonic eras, the Amish sought a place where they could transplant and continue their life and traditions as they had established them in Europe, centered in tightly knit, traditionalist agrarian communities (Séguy 1984, 212-13). 


\section{The Appeal of the Apostolic Christian Message on the German-Speaking American Frontier}

For those of an Amish or Mennonite background, the Apostolic Christian movement presented a viable option for both continuity and change. It provided continuity in the essential aspects of an Anabaptist identity — believers' baptism, nonresistance, and a strong sense of a corporate peoplehood and separation from the world. Yet, the Apostolic Christian tradition also presented opportunity for change. As with other similar nineteenth century Neo-Anabaptist movements of renewal, the Apostolic Christian Church served as a mediator of evangelical Pietistic renewal, as in an orientation toward an essential, personal appropriation of faith rather than simple willingness to abide by the Ordnung.

The spread of the Apostolic Christian movement among the nineteenth century European Amish immigrant communities anticipated, by a generation, similar movements of renewal that would take root in these Amish and Mennonite communities. ${ }^{3}$ The German language, along with renewal themes that appealed to a German-European mentality, made possible avenues of renewal among the immigrant communities that American revivalists and evangelists did not yet have. The Neutäufer Zions Harfe hymnal, in particular, served as a bridge of critical modernization and renewal through its creative tension between, one, traditional Amish and Mennonite emphases of martyrdom and hope for those who patiently endure the rejection and suffering naturally due those who follow Christ, and, two, Pietist notions present in many of the eighteenth and nineteenth century hymns.

Although the Neutäufer movement drew from much the same nineteenth century evangelical neo-Pietist sources as did American Revivalism (Stoeffler 1976), the German speaking communities, and especially recent immigrant communities, were still resistant to the influences of Anglo-American forms of religious piety (Nolt 2002, 47-65). Not until these communities had themselves undergone a certain degree of Americanization would some of them be open to such influences - though even then many have resisted such influences, even to the present day.

The first congregation of Neutäufer was established in Lewis County, New York, among a recent settlement of Amish. Conditions seemed to have been similar to those among the Emmental Mennonites in Switzerland. The Amish of Lewis County had been settled in the region of Croghan, New York, for just a decade (since 1837) when Fröhlich, in 1847, sent the first apostle of the Neutäufer, Benedict Weyeneth, to the Amish of Lewis County, at the request of the Amish bishop (Bender 1964, 6; Klopfenstein 1984, 78). The area had been settled from the 1830s through the 1850s by Amish-Mennonites emigrating from the region Alsace-Lorrain, France-primarily from the vicinity of Metz (Yousey 1987, 26-39). Most of these immigrants left France in response to the new compulsory military service laws in France. 
Yousey $(1987,48)$ reports that there had been a good deal of turbulence within the community concerning issues of faith and religious practices, which lead up to the invitation. Particularly adamant in the push for change was Amish-Mennonite minister, Rudolph Virkler. When Weyeneth asked if he would be permitted to read to the congregation a song, Virkler consented. Weyeneth's speech concerned the necessity of the New Birth experience and the necessity of a baptism of faith by immersion. After hearing Weyeneth's preaching from the Scriptures, "Be baptized, every one of you," Virkler and his family left the Amish-Mennonite Church to begin the first Apostolic Christian church in North America. Because there was not sufficient evidence of a radical conversion, the Amish baptism was considered invalid and those joining the new movement had to be baptized again. Here we see the exclusive and separatist nature of Fröhlich's teachings shaping the new American church at a fundamental level. A nineteenth century Amish-Mennonite account of the Neutäufer (also popularly called "New Amish”) reads:

They had themselves [the Amish-Mennonite converts] baptized again. Their main doctrines were that no person could be saved unless they belonged to their church, the form of baptism had to be immersion, and they made a big thing of the New Birth. (Quoted in Yousey 1987, 52-53)

The Neutäufer movement gained further traction among the Amish-Mennonite immigrants. Two years later, Bishop Joseph Farney left to join the Neutäufer. The remaining members called upon neighboring bishops in Canada and Pennsylvania to ordain new ministers for them, yet even many of these new leaders eventually joined the Neutäufer. In all, about threefourths of the Amish-Mennonite community in the Lewis County vicinity joined with the “Evangelical Baptists” (Neutäufer) during the 1840s and 1850s (Yousey 1987, 48).

By the early 1850s, inroads had been made among the Amish-Mennonites of central Illinois, in Woodford County, in the vicinity of Partridge Prairie, near Metamora. Conditions there were very primitive at the time and worship services were conducted in a barn, with some attendees walking as far as 25 miles for services (Estes 1984, 76-79). Through a number of circumstances, Illinois would become a major center of what would come to be called the Apostolic Christian Church in America. The availability of inexpensive, undeveloped land attracted many German-speaking immigrants, including a large number of Amish-Mennonites as well as a number from Fröhlich’s movement in Switzerland.

By the 1860s, a significant portion of the Swiss Mennonites of the Chippewa, Ohio, community (later Crown Hill Mennonite Congregation) had left to form the Apostolic Christian Church of Rittman, Ohio (Lehman 1975, 28-30). This is now one of the largest Apostolic Christian congregations in the world, with over 1,000 in weekly attendance. A similar defection occurred around the same time among the Amish-Mennonite settlers of Davis County, Iowa, with prominent Amish minister Christ Kropf leaving the Amish-Mennonite Church to help organize the Apostolic Christian Church in that area. The emphasis on immersion baptism was a key factor (Gingerich 1939, 62). 
A similar movement occurred in Northeast Indiana in Allen, Wells, and Adams Counties in 1862, which had received a large number of Amish-Mennonite immigrants in the preceding decades (Ringenberg 1976, 114-22). This led to the establishment of two of the historically strong Apostolic Christian congregations of Bluffton and Leo. Similarly a group from the large Swiss Mennonite community of Berne, Indiana, left that community to join the Apostolic Christian Church (Wenger 1961, 357).

The new Apostolic Christian faith also appealed to recently arrived Swiss Mennonite immigrants in the Willamette Valley of Oregon. Led by Christian C. Wenger (from Ohio, whose father was a Swiss immigrant), many of these disorganized Swiss Mennonites joined the Apostolic Christian church, as the Apostolics were the first to care for their spiritual needs. They were also attracted by the "warm piety" and "definite salvation experience" that the Apostolic Christians emphasized (Lind 1990, 137-38).

A portion of the early Apostolic Christian believers in America were not of Amish or Mennonite background. A number of these believers were immigrant members of the Neutäufer congregations in Europe. One fascinating case is the transplant of the entire congregation of Schweinfurt, Bavaria_led by Andrew Braun—to Peoria, Illinois in 1854 (Braun, n.d.; Ruegger 1949, 157-59). The motivation in this case was freedom to practice their new faith freely. Congregations at Sardis, Mansfield, and Girard in Ohio; New Martinsville in West Virginia; and Elgin and West Bend in Iowa were all founded primarily by Swiss and German immigrants from non-Mennonite/Amish background. However, the vast majority of the early Apostolic Christian converts in American came from Amish and Mennonite background, with strong roots in Swiss Anabaptist traditions.

Thus, the story of the establishment of the Neutäufer or Apostolic Christian Church movement in America occurs within the matrix of an isolated new-immigrant frontier community. It is arguable that the migration experience was in large part responsible for this change in attitude. Separated from the context that had shaped their faith for roughly two centuries, the Amish communities in America were forced to ask new questions concerning their own faith and identity, especially in relation to the new world in which they now found themselves, where systemic discrimination no longer characterized their relationship to their new social environment.

Similar to the Emmental Mennonite congregation that Fröhlich encountered in the 1830s, the Amish-Mennonites of the 1840s and 1850s had come to a general sense of social unrest. In the new context of the American frontier, new questions were being asked. Whereas, in the past, strict adherence to social and communal norms provided the Amish in Europe a sense of solidarity against social pressures of an antagonistic dominant society and regime, they no longer served such a purpose in the New World. Now, alternate visions of Anabaptist Christian identity could-perhaps must - emerge beyond the categories of mere communal survival and preservation. Strict adherence to the "Old Order" would only be one answer to the new 
questions. Defections to the Neutäufer in the 1840s to the 1860s were symptomatic of the internal communal tensions that had been mounting within the Amish community since the 1830s, between "change minded” Amish-Mennonites and Old Order traditionalists. This would eventuate in lasting schisms, despite efforts in the mid-1860s to bring compromise and reconciliation (Yoder 1991, esp. 135-170).

\section{Sectarian Consolidation and Ethnicization}

The Amish-Mennonite immigration had passed its peak after the 1850s and largely ceased by 1860 (Nolt 2003, 222). As the new communities developed in both social and economic stability, so had the religious communities of the Midwest stabilized by and large. A cultural synthesis was emerging that would characterize the new rural American Midwest, as it transitioned from America's swampy wild frontier, to America's bread basket. Customs and cultural adaptations became established, blending the older Amish traditions with the new faith, forming a new "sacred canopy" (Berger 1967). A religio-ethnic synthesis was emerging, which would only come to be solidified and crystallized in the preservationist attitudes of the second and third generation descendants of the original immigrants.

A major and critical adjustment that the Apostolic Christians would have to make within the American context was the relative lack of persecution, which had been a major facet of their identity formation in Europe. No longer a minority in the face of a gargantuan government and state church prejudiced against them, they now settled in the frontier areas of the early nineteenth century America, where they would find abundant freedom and resources make their own way. They were now but one religious sect in a land of sects, where no one religious group predominated. As American historian James E. Davis observes in his history of early emerging Illinois frontier society (to which immigration of Apostolic Christians contributed a significant portion):

Growing frontier diversity, perhaps ironically, helped strengthen consensus. By the 1830s or so, no single social or political segment could dominate all others. Like it or not, people were stuck with each other [...] Illinois - especially the northern two thirds — was an admixture of French, French-Indian, Southern, Yankee, English, Irish, German, and other folk, as well as offspring of countless mixed marriages. The mixed population resembled that of the Middle Atlantic region during colonial times and later. Like that region, Illinois experienced social and political strife, which led to fluid coalitions, fragile compromises, and cautious restraint, but not horrendous conflict. Consensus often emerged because factions realized that pushing things to extremes was neither possible nor desirable. Furthermore, a toleration, however grudging, of strange neighbors became the norm, not the exception. Toleration did not imply acceptance, but it did mean that pragmatic live-and-let-live sentiments pervaded society. (Davis 1998, 310)

As with other religious minority groups, it was in this tolerant frontier setting that the Apostolic Christian Church could find its niche, its own piece of the promised land, where it and its people would live in peace and holiness, separate from the world, until the consummation of 
God's Kingdom on earth. In the frontier areas, where no clear culture yet predominated, they would find the freedom to establish and shape their own communal and religious identity, in the vast wilderness that would become the heartland of the American Midwest. They thus came into a new position of becoming culture-shapers as much as those shaped by the dominant culture around them, both through their settlement and cultivation of the land, as well as their significant place in developing the economic establishment in the small towns and rural counties of central Illinois and other areas in the Midwest, even as they sought to maintain a separatist existence. Because of the Apostolic Christian taboos toward exogamy (marriage outside of the community) and strict doctrine of "non-fraternization" with those outside the church community, they have maintained a unique religious-ethnic identity that distinguishes them to the present. They would always shape, and be shaped by, the dominant rural Midwestern culture around them — a part of what Davis $(1998,310)$ calls the "Illinoisan hybrid culture."

The travel journal of a second generation Swiss Neutäufer, Heinrich Geistlich, a Neutäufer elder from Meilen, Switzerland, provides an invaluable resource for insight into the social, cultural, economic, and religious transitions that were occurring, which were bringing about subtle shifts in the religio-cultural Anabaptist identity of the Neutäufer. As Geistlich (1866, 15) noted in his 1866 travel journal, land prices were no longer so attractively cheap for newcoming immigrants as they had been for the pioneer settlers of the 1840s and 1850s. In a journal entry of June 4, Geistlich noted that the land was still quite wild and that it would take much hard work to make the land profitable. Describing the close knit nature of the community, Geistlich reports: "They live close together and through raising cattle have a pleasant and quiet life." Going on to note the economic development and prosperity that the immigrant communities had achieved in two decades, he writes: "They are for the most part well to do" and "are wealthy men now" (pp. 8-9). In Croghan, New York, Geistlich also noted that, due to development, the land is no longer as cheap as it was when the settlers first arrived: "For the most part they have lived here for a long time and are now nearly all well to do, having made good, as in earlier times the land was as low as $\$ 5.00$ an acre and now it is $\$ 20.00$ or more. They also have a good market and get a high price for their produce” (p. 12).

Geistlich also noted that there were tensions within the communities, between those who were of different nationalities and between the older and the more recent immigrants:

[Joseph Bella] complained to me of the domineering actions of some of the brethren toward him, brethren of foreign birth also complaining the same [...] there appears a difference in the customs and habits of the different nationalities which cannot quite agree with each other, so this difference then appears to be here between them that came from the old country and the Americans who were here longer. (Geistlich 1866, 15)

Many of those with whom Geistlich conversed were immigrants and shared memories of the old world. He was presented a letter from Switzerland to review, which evidences that communications were kept with the immigrants' homeland during this time. Encouraged by good 
reports, family members continued migrating when possible. Geistlich notes that many of the Swiss and German immigrants that he encountered - most having immigrated a decade or two before-expressed a profound homesickness (p. 14). Yet, this was even as they were attempting to reconstruct their European homeland in the New World, as they cleared the forests, tilled the prairies, and built new towns and villages after European models, though pragmatically adapted to contextual realities of the American frontier.

Geistlich witnessed a number of church practices and rituals during his time and was often the guest officiant. He preached at a funeral and performed a baptism in a local river. Geistlich notes that the American church practices differed from Switzerland in that American churches had their own cemeteries, and that Americans had the freedom to baptize in open daylight, both forbidden in Switzerland (pp. 11-12). He also noted that the brethren there met daily for church, because they had the freedom of time that those in Switzerland had not.

This experience of relative toleration would be a rather different experience from their fellow believers in Europe, at least for another half century in Switzerland, and more than a century and a half in Eastern Europe. We can see here the emergence of a new ethnicity. In the new German immigrant culture on the American Midwestern frontier, it would seem that the Apostolic Christians of nineteenth century America were undergoing their own process of “ethnicization” as a part of their own Americanization process (cf. Nolt 2002, 4).Though initially spreading among first generation German-speaking immigrants from Switzerland, Germany, and France, by immigrant missionaries and leaders from these same countries, the Americanization process occurred almost immediately through the necessary and inevitable social and cultural adaptations that had to occur as the European immigrants were forced to adapt to the realities of American frontier life. The untamed frontier and inflow of immigrants gave them space to acculturate without being fully assimilated (see Gordon 1964, 70-71; cf. Lagerquist 1991, 57).

\section{From Forced Exile to Self-Exile}

Like other Anabaptist communities with an American experience, Apostolic Christian identity in America thus soon shifted from a mentality of martyr complex shaped by persecution through official legal sanction and discrimination to a mentality of preservation as a moral, ethno-religious, and pure remnant, only separate now not from a powerful, dominant Satanic false church—epitomized in the "Constantinian" state church—but now from plurality of competing sects representing the confusion of idolatrous Babel. In this understanding, Babel represented human frustration, confusion, and strife, inevitably resting on false, human-derived doctrines. The Apostolic Christian Church was thus idealized as the church of harmony, peace, and true holiness - of one accord, resting on the true foundations of Christ and the Apostles, absolutely unified in doctrine and spirit. Thus, their identity was now centered on the central issue of the purity of their faith and doctrine and practices, over against the myriad of competing faiths around them. A tract What is Babel? (Or: Confusion) by S.J. Braun and P.I. Schiler (1937) describes concisely the mentality that had set in among Apostolic Christians during the 
nineteenth century. Although this mentality of opposition to Babel is to be found from the European roots of the movement as well—particularly epitomized in Fröhlich's rejection of relationships or alliances with other emerging Free Church traditions-it was secondary to the larger conflict with the State Church. In America, however, where plurality of independent denominations and free churches abounded, the latter would become the primary device for conceiving of Apostolic Christian identity in relation to the wider world. In time, it would come more to the fore in the Western European communities, as Swiss and German society and government became more tolerant and liberalized. But never would dissenting religions reach the same degree of respect and popularity as in the American pluralist context. This only contributed to their developing ethnicization, as Apostolic Christians came increasingly to crystallize their communal rituals, and to define what it meant to be "separate" and "pure and unspotted" from the world. ${ }^{4}$

In the American context the Apostolic Christian people lived mostly peaceable lives. They aided in the social, cultural, and ecological transformation of their new homes from the wild American frontier to the expanse of cultivated fields of the American Midwest. Within the farming villages and communities of these European settlers, the people attempted to preserve the cultural patterns of language, dress, and piety as they had inherited them from Europe. The immigration of several key leaders from Europe, including Benedict Weyeneth and Joseph Bella ensured that the early foundation of the Apostolic Christian Church would have a strong basis and guidance in its first generation and strong sense of continuity with the Neutäufer movement in Europe. Their creativity and charisma further aided in navigating various issues and tensions faced by new religious movements that bring together diverse elements.

However, with the death of the first generation leaders and of the ebbing of SwissGerman immigration to the Midwest, Apostolic Christians settled into a maintenance orientation in the second generation, seeking to consolidate and preserve the forms of faith and piety bequeathed to them by the first generation. The maintenance of German language, coupled with a rural-based isolationism, served to insulate the community from outside influences and slow adaptation to changes in wider society (Sutter 1968, 65-76). The concepts of holiness and separation from the world became codified in strict regulations of community life and taboos, including codes of appropriate uniformity of dress and common definition of "plainness." Notions of change would be suspect as compromising with the world. So long as the community remained relatively isolated and homogenous, there was a sense of social stasis.

However, beginning around the year 1890 and lasting into the first decade of the twentieth century, a new wave of Nazarene immigrants from Eastern Europe would arrive, and the specter of cultural pluralism would provide a new challenge to assumptions about the homogenous religio-ethnic identity of American Apostolic Christians. 


\section{Into the 20th Century: The Challenge of Cultural Pluralism and Sectarian Fragmentation}

\section{The Nazarenes: An Emergent, Indigenous, Eastern European Neo-Anabaptist Movement}

The story of the Nazarenes is a fascinating one. Two men of Budapest who were studying the watch-making trade in Switzerland had encountered Fröhlich and his teaching and were won over. They sought to bring the Neutäufer faith to their homeland. At the same time that Weyeneth had gone to spread Fröhlich's message in America, Lajos Hencsey was evangelizing the countryside of southern Hungary, establishing the new movement there (Eotvos 2006). His followers became known as Nazarenes, followers of Jesus the Nazarene. The Nazarene movement grew rapidly, and followers were persecuted heavily, both because they were growing rapidly and because of their characteristically Anabaptist conviction of nonresistance and refusal to take up weapons (Brock 1980, 1983). Because of the multi-ethnic nature of the AustroHungarian Empire, the Nazarene worship services came to be conducted in German, Hungarian, Serbian, and Romanian. The Nazarenes were faithful proponents of Fröhlich's key teachings on faith and practice, including purity and plainness, though these took on different cultural expressions from their Swiss and Amish-Mennonite brethren in the West.

Following larger trends of Eastern European immigration to North America, large numbers of Nazarenes moved to the United States, for reasons of both economic opportunity and religious freedom. Eastern European immigration was especially heavy in Northeast Ohio, which led to the establishment of ethnic Eastern European congregations in Cleveland, Warren, Wooster, Barberton, and Akron. Congregations were also formed in other industrial areas, especially on the eastern seaboard, including New Haven, CT; Richmond, VA; and Sharon and Erie, PA. All of these were areas in which there was major growth and development of heavy industries, which drew large numbers of immigrants from southern and central Europe. Congregations which were already located in or near urban industrial areas, such as Mansfield, $\mathrm{OH}$, or Chicago, IL, would also receive an influx of immigrants, soon causing tensions over issues of language and custom. The new waves of immigration from Central and Eastern Europe of the late nineteenth and early twentieth centuries - which included many of those who came to embrace the Nazarene faith outlined above-would pose a challenge to the identity of the Apostolic Christian churches in America in an unprecedented way.

\section{Cultural Conflict and Apostolic Christian Identity}

An account of one of newly arrived Hungarian immigrant family has been preserved. This is the story of Wendel Kalman and his family, who immigrated to the United States in 1892. In this story, written 29 years after the fact, Kalman narrates the experience of him and his family in their first years in Fairbury, Illinois. Kalman reports that upon his arrival to Fairbury, Kalman was immediately informed by the Elder Martin Steidinger that he would have to conform to the 
order and discipline in America, which prohibited the wearing of mustaches. Kalman also relates that his wife, Barbara, at first wore a traditional Eastern European scarf as a head covering but was soon admonished that the women of the church would be more accepting of her if she would dress as the other women—wearing a "plain hat" of their style instead. Kalman reports Barbara's response: "Now I can see, that here love is merely attached to costumes and dresses." Kalman reports that he agreed that it was the same attitude with mustaches. He further relates that another Hungarian Nazarene was greeted at port on his arrival by ship but was rejected because of his mustache, so he returned to Hungary with a "bleeding heart" (Kalman 1921, 1).

When another group of Hungarian Nazarenes arrived at Fairbury, they were told by Steidinger that they would be welcomed only on condition that they submit to the discipline and agree to shave off their mustaches. A number of brethren were taken aback by what they considered to be an unbiblical man-made doctrine completely foreign to their cultural norms. After several warnings, many of them submitted at first and shaved but were stricken in conscience and thereafter refused. This eventually led to their punishment for not submitting to the discipline (Kalman 1921, 2). Kalman was himself eventually expelled over the issue and only restored after the formation of the new Apostolic Christian Church (Nazarene). Such actions reflected growing tensions within the Apostolic Christian congregations, especially as more and more immigrants arrived and certain elders became stricter in their discipline to maintain uniformity.

The "flood stage" of immigration to the Akron area, which included thousands of Eastern Europeans, was 1905-1907, and included a substantial number of Nazarenes. The years of the division, 1906-1907, also corresponded to the height of immigrations from the Austro-Hungarian Empire, particularly of ethnic Serbs and Slovaks to Ohio and Illinois (Shipman 1912), where numerous Apostolic Christian Churches, primarily of Swiss-German background, already existed. So great and ethnically varied was the influx of immigrants to the area that five separate congregations had been established to accommodate services in each of the various languages represented in the multi-ethnic Pannonian basin of southern Austria-Hungary. These included German, Serbian, Hungarian, and Slovak (Pavkov and Pavkov 1989, 30-32).

\section{Discipline, Dissent, Division, and Definition of Communal Identity}

By 1906, tensions had reached a critical point. Congregations and groups of people, comprising about one fourth of the entire membership of the Apostolic Christian Church at the time, withdrew to form a new association, the Apostolic Christian Church (Nazarene), or ACCN. The addition of the qualifier "Nazarene" indicates an enduring identification with the Eastern European constituency of the movement. Many of the new ACCN churches were located in urban areas, reflecting new trends in settlement. At the time of the division, the ACCN had most of its strength in urban areas. For example, the majority of the Apostolic Christian congregation in Portland, Oregon, favored the ACCN side—-this even though few Eastern Europeans had settled there- leaving only a handful of members who chose to affiliate with the ACCA 
(Klopfenstein 1984, 245, 252-53). The ACCN thus represented a hybrid coalition of more urban, progressive Swiss-American and Eastern European Nazarenes. While still a very exclusive and separatist sect in its own right, the ACCN had collectively taken a step away from stringent uniformity of nineteenth century Amish-Mennonite forms and embraced a more culturally pluralistic expression of their common faith.

Although maintaining such familial and often cordial informal relations, the precedents of the division set the two denominations on two different trajectories. The majority group would later come to be known as the Apostolic Christian Church of America, or ACCA. ACCA consisted mostly of those in rural areas and with Swiss Mennonite / Amish backgrounds. The ACCA would tend to be more conservative and set in nineteenth century Midwestern Germanic immigrant culture. The ACCN would be more flexible in regards to issues of cultural relativity and would develop a stronger missionary spirit. This movement would also be more generally oriented toward Europe for much of the twentieth century, due to the fact that after the division, most European immigrants of the faith would settle in the ACCN congregations. Since none of the American-born elders chose to join the new denomination, the ACCN would look to a new European-born immigrant eldership, with the result of stronger links with Europe and especially of social concerns of persecution and suffering of their fellow believers during the war years.

For American Apostolic Christians, the twentieth century began with turmoil, and it would become a century of fractiousness. The golden age of the Fröhlichite movement were truly during the greater part of the nineteenth century. So long as the different communities remained in their own geographical and cultural spheres, referring to the others as "brethren" was not difficult. However, when two different cultures came to meet in the same congregation in North America, cultural assumptions hitherto assumed came to the fore as major issues. What began as an evangelical -Pietist renewal movement in the 1820s, increasingly due to circumstances of historical context, by late nineteenth century had become an institutionalized, ethnicized sect. Fröhlich's movement initially found its sectarian identity in a new understanding of baptism and a new appropriation of traditional Anabaptist beliefs, owing much of its force to the broader renewal movements from which it had emerged. Competition not only with the State Church, but also with other baptistic groups, marked the radical separatism of the Fröhlichites and its successor movements firmly as a sect and not merely as a denomination. The continual need for self-definition over against other groups, and the identity of a faithful remnant reinforced an emphasis on nonconformity and separation from the world.

This proclivity toward negative-identity formation thus resulted in a worldview of inherent in-group conformity, conservatism, and homogeneity. This preoccupation led to a fixation on boundary setting and the need for well-defined codification of behavioral expectations of members and stern sanctions for violations. Moreover, the difficulty in coping with the contextual nature of these formulations has further complicated and exacerbated the issues, as seen in the tendency toward fractiousness. All Apostolic Christians could fundamentally agree that they should live plainly and not be conformed to worldliness. The 
challenge has ever been defining precisely what that means—and, moreover, to what degree differing formulations can be recognized and appreciated.

\section{Endnotes}

${ }^{1}$ Wilhelm Martin Lebrecht De Wette (1780-1849) was one of the foremost rationalist Bible scholars and theologians of the early nineteenth century. He was often referred to as the "Father of Biblical Criticism.” John W. Rogerson (1992, 191-97), the modern authoritative biographer of De Wette, gives a thorough account of the theological curriculum that DeWette in 1823 instituted at the University of Basel, which Samuel Fröhlich would have studied during his time there.

2 “Letter to Baptist Preachers’ Conference,” September 4, 1856, in Fröhlich (n.d., 46).

${ }^{3}$ The "Egly Amish" followed the closest behind the emergence of the Apostolic Christian Church in America and was in turn followed by a variety of late nineteenth and early twentieth century movements that would draw from mainstream American revivalism as a source of renewal for their communities, such as the Missionary Church Association and Conservative Mennonite Conference (Rosedale).

${ }^{4}$ Maureen Tilley (1997, 21-35) observes a similar trend that occurred in the Donatist Church of ancient Roman North Africa in the fourth through fifth centuries. Donatism, as Tilley notes, had emerged around the issues of preserving the faith and heritage of the martyrs against the compromises of allowing the lapsed to be readmitted to the church. In time, the "catholic" side of the schism gained the support of the Roman state and had occasionally used state power against the Donatists, which Augustine legitimated in his theological arguments. However, Tilley contends that these times of persecution were not always ongoing and that in many places Donatism was the more prevalent and powerful religious force. Thus, Tilley argues, the more useful Donatist conception of self-image and identity was that of faithful assembly of a ritually pure and distinct Israel, set apart from the impure world around them. This sustained Donatist identity in times when persecution and the prospect of martyrdom were not so overt and helped to guard against the more subtle threat of assimilation.

\section{References}

Alder, Garfield. 1980. Die Tauf- Und Kirchenfrage in Leben Und Lehre Des Samuel Heinrich Fröhlich. Bern, Switzerland: Peter Lang.

Bender, Arletha Zehr. 1964. A History of the Mennonites in Croghan and Lowville, New York. Berger, Peter. 1967. The Sacred Canopy: Elements of a Sociological Theory of Religion. New York, NY: Anchor.

Braun, S.J. n.d. My Father’s Conversion. Syracuse, NY: Apostolic Christian Publishing Co. 
Braun, S.J., and P.I. Schiler. 1937. What Is Babel? (Or: Confusion). Syracuse, NY: Apostolic Christian Publishing Co.

Brock, Peter. 1980. “The Nonresistance of the Hungarian Nazarenes to 1914.” Mennonite Quarterly Review 54(1):53-63.

—. 1983. "Some Materials on Nazarene Conscientious Objectors in Nineteenth-Century Hungary.” Mennonite Quarterly Review 57(1):64-72.

Davis, James E. 1998. Frontier Illinois. A History of the Trans-Appalachian Frontier. Bloomington, IN: Indiana University Press.

Dieter, Melvin Easterday. 1996. The Holiness Revival of the Nineteenth Century [2 ${ }^{\text {nd }}$ ed.]. Lanham, MD: Scarecrow Press.

Durnbaugh, Donald. 1968. The Believers' Church: The History and Character of Radical Protestantism. New York, NY: Macmillan.

Eotvos, Karoly. 2006. The Nazarenes [ $2^{\text {nd }}$ ed.]. Edited by Perry Klopfenstein, trans. by Joseph Csaba. Fort Scott, KS: Sekan.

Estes, Steven. 1984. Living Stones: A History of the Metamora Mennonite Church. Metamora, IL: Metamora Mennonite Church.

Fath, Sébastien. 2003. “A Forgotten Missionary Link: The Baptist Continental Society in France (1831-1836).” Baptist Quarterly 40(3):133-51. https://doi.org/10.1179/bqu.2003.40.3.002

Fröhlich, Samuel Heinrich. 1978a. Baptismal Truth: The Salvation of Man through the Baptism of Regeneration and the Receiving of the Holy Spirit A Scriptural Discourse Concerning the Baptism in Christ. Eureka, IL: Apostolic Christian Publications.

—. 1978b. Evidence Demonstrating the Truth of the Word of God. Eureka, IL: Apostolic Christian Publications.

—. n.d. Writings of S.H. Froehlich. Version 29. Fairbury, IL: Heritage Center Foundation.

Garrett, James Leo. 2009. Baptist Theology: A Four-Century Study. Macon, GA: Mercer University Press.

Geistlich, Henry. 1866. “The Journey of Brother Henry Geistlich, Elder of Meilen, Switzerland to the United States in 1866.” Unpublished travel journal.

Gingerich, Melvin. 1939. The Mennonites in Iowa. Iowa City, IA: State Historical Society of Iowa. 
Gordon, Milton. 1964. Assimilation in American Life: The Role of Race, Religion, and National Origins. New York, NY: Oxford University Press.

Gratz, Delbert. 1953. Bernese Anabaptists and Their American Descendents. Scottdale, PA: Herald Press.

Hadorn, W. 1901. Geschichte Des Pietismus in Den Schweizerischen Reformierten Kirchen. Konstanz: Carl Hirsch.

Kalman, Wendel. 1921. “Account of First Experiences of America.” Transcripted narrative account. Akron, OH. (https://www.scribd.com/document/47105388/Account-of-FirstExperiences-in-America-by-Wendel-Kalman)

Klopfenstein, Perry. 1984. Marching to Zion: A History of the Apostolic Christian Church of America, 1847-1982. Fort Scott, KS: Sekan.

Krahn, Cornelius, and John J. Friesen. 1989. “Elder (Ältester).” Global Anabaptist Mennonite Encyclopedia Online. (http://gameo.org/index.php?title=Elder_(\%C3\%84ltester)\&oldid $=144987$ )

Lagerquist, L. DeAne. 1991. In America the Men Milk the Cows: Factors of Gender, Ethnicity, and Religion in the Americanization of Norwegian American Women. Brooklyn, NY: Carlson.

Lehman, James O. 1975. Crosswinds: From Switzerland to Crown Hill. Rittman, OH: Crown Hill Mennonite Church.

Lehmann, Hartmut. 2000. “Die Neue Lage.” In Der Pietismus Im Neunzehnten Und Zwanzigsten Jahrhundert. Vol. 3. Geschichte Des Pietismus. Göttingen: Vandenhoek \& Ruprecht.

Lind, Hope Kauffman. 1990. Apart \& Together: Mennonites in Oregon and Neighboring States 1876-1976. Scottdale, PA: Herald Press.

Mangold, G.M. 1950. Meditations upon the Past, Present, and Future: Remarks about the Revelations of Jesus Christ Unto His Servant John. Trans. by Ernest Graf Sr. Akron, $\mathrm{OH}$.

McBeth, H. Leon. 1987. The Baptist Heritage: Four Centuries of Baptist Witness. Nashville, TN: Broadman Press.

Moser, Robert Edward. 1973. "The Origin, Content, and Development of the Zion’s Harp, Hymnal of the Apostolic Christian Church of America.” M.S. thesis in education. Normal, IL: Illinois State University. 
Nolt, Steven M. 2002. Foreigners in Their Own Land: Pennsylvania Germans in the Early Republic. University Park, PA: Pennsylvania State University Press.

—. 2003. A History of the Amish. Intercourse, PA: Good Books.

Ott, Bernhard. 1996. Missionarische Gemeinde Werden: Der Weg Der Evangelischen Täufergemeinden. Uster, Switzerland: ETG Verlag.

Pavkov, Ted, and Ernie Pavkov. 1989. “Akron Area Church, 1903-1989.” Pp. 29-38 in Mountaintops along the Way: Essays in the History of the Apostolic Christian Church of North America (Nazarean), edited by Dorothy P. Feucht, Janice Sheetz, Joseph E. Haring, Marilyn Swinford, and Nancy Haag. Tremont, IL: Apostolic Christian Church Foundation.

Ringenberg, William. 1976. "Development and Division in the Mennonite Community in Allen County, Indiana.” Mennonite Quarterly Review 50(2):114-31.

Rogerson, John W. 1992. W.M.L de Wette, Founder of Modern Biblical Criticism: An Intellectual Biography. Sheffield, UK: Sheffield Academic Press.

Ruegger, Hermann. 1949. Apostolic Christian Church History. Chicago, IL: Apostolic Christian Publishing Co.

Séguy, Jean. 1973. "Religion and Agricultural Success: The Vocational Life of the French Anabaptists from the Seventeenth to the Nineteenth Centuries.” Mennonite Quarterly Review 47(3):179-224.

—. 1984. "The French Anabaptists: Four and One-Half Centuries of History.” Mennonite Quarterly Review 58(3):206-17.

Shipman, Andrew. 1912. “The Slavs in America.” The Catholic Encyclopedia. New York, NY: Robert Appleton. (http://www.newadvent.org/cathen/14051a.htm).

Stark, Werner. 1970. The Sociology of Religion, A Study of Christendom, Volume Four: Types of Religious Man. New York, NY: Fordham University Press.

Stoeffler, F. Ernest. 1973. German Pietism During the Eighteenth Century. Leiden: E.J. Brill.

—. 1976. "Pietism, the Wesleys, and Methodist Beginnings in America.” Pp. 184-221 in Continental Pietism and Early American Christianity, edited by F. Ernest Stoeffler. Grand Rapids, MI: Eerdmans.

Sutter, Darrel A. 1968. “The Anabaptist Apostolic Christian Church of America.” M.S. thesis. Normal, IL: Illinois State University. 
Tilley, Maureen. 1997. "Sustaining Donatist Self-Identity: From the Church of the Martyrs to the Collecta of the Desert.” Journal of Early Christian Studies 5(1):21-35. https://doi.org/10.1353/earl.1997.0030

Wenger, John Christian. 1961. The Mennonites in Indiana and Michigan. Scottdale, PA: Herald Press.

Yoder, Paton. 1991. Tradition and Transition: Amish Mennonites and the Old Order Amish 1800-1900. Scottdale, PA: Herald Press.

Yousey, Arlene. 1987. Strangers and Pilgrims: History of Lewis County Mennonites. Croghan, NY: Self Published. 